\title{
Dramatic Experience
}




\title{
Drama and Theatre in Early Modern Europe
}

\author{
Editor-in-Chief
}

Jan Bloemendal (Huygens Institute for the History of the Netherlands)

\section{Editorial Board}

Cora Dietl (Justus-Liebig-Universität Gießen )

Peter G.F. Eversmann (University of Amsterdam)

Jelle Koopmans (University of Amsterdam)

Russell J. Leo (Princeton University)

VOLUME 6

The titles published in this series are listed at brill.com/dtem 


\title{
Dramatic Experience
}

\author{
The Poetics of Drama \\ and the Early Modern Public Sphere(s)
}

Edited by

Katja Gvozdeva, Tatiana Korneeva, and Kirill Ospovat

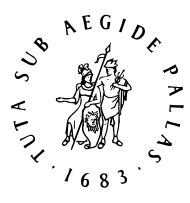

B R I L L

LEIDEN | BOSTON 

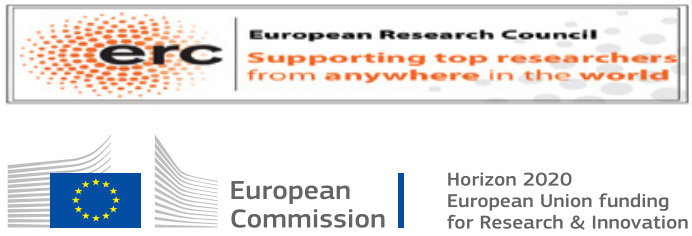

B R I L L This is an open access title distributed under the terms of the CC-BY-NC License, which O P E N permits any non-commercial use, distribution, and reproduction in any medium, provided the original author(s) and source are credited.

Cover illustration: Bauerntheater (Peasants' Theatre), by Jakob Placidus Altmutter, c. 1805. Pen-and-wash drawing, $179 \times 254$ mm. Courtesy of Innsbruck, Tiroler Landesmuseum Ferdinandeum, Grafische Sammlungen, TBar/1149.

The Library of Congress Cataloging-in-Publication Data is available online at http://catalog.loc.gov LC record available at http://lccn.loc.gov/

Typeface for the Latin, Greek, and Cyrillic scripts: “Brill”. See and download: brill.com/brill-typeface.

ISSN 2211-341X

ISBN 978-90-04-32975-1 (hardback)

ISBN 978-90-04-32976-8 (e-book)

Copyright 2017 by the Editors and the Authors.

This work is published by Koninklijke Brill NV. Koninklijke Brill NV incorporates the imprints Brill, Brill Hes \& De Graaf, Brill Nijhoff, Brill Rodopi and Hotei Publishing.

Koninklijke Brill NV reserves the right to protect the publication against unauthorized use and to authorize dissemination by means of offprints, legitimate photocopies, microform editions, reprints, translations, and secondary information sources, such as abstracting and indexing services including databases. Requests for commercial re-use, use of parts of the publication, and/or translations must be addressed to Koninklijke Brill NV.

This book is printed on acid-free paper and produced in a sustainable manner. 


\section{Contents}

Acknowledgments VII

List of Illustrations and Tables VIII

Contributor Biographies IX

Introduction: Dramatic Experience: The Poetics of Drama and the Early Modern Public Sphere(s) 1

Katja Gvozdeva, Tatiana Korneeva, and Kirill Ospovat

1 Opening Spaces for the Reading Audience: Fernando de Rojas's Celestina (1499/1502) and Niccolò Machiavelli's Mandragola (1518) 13

Sven Thorsten Kilian

2 Why Do Men Go Blind in the Theatre? Gender Riddles and Fools' Play in the Italian Renaissance Comedy Gl'Ingannati (1532) 35

Katja Gvozdeva

3 The Accademia degli Alterati and the Invention of a New Form of Dramatic Experience: Myth, Allegory, and Theory in Jacopo Peri's and Ottavio Rinuccini's Euridice (1600) 77

Déborah Blocker

4 Il favore degli dei (1690): Meta-Opera and Metamorphoses at the Farnese Court 118

Wendy Heller

5 Entertainment for Melancholics: The Public and the Public Stage in Carlo Gozzi's L'Amore delle tre melarance 140

Tatiana Korneeva

6 Pierre Nicole, Jean-Baptiste Dubos, and the Psychological Experience of Theatrical Performance in Early Modern France 172

Logan J. Connors

7 The Catharsis of Prosecution: Royal Violence, Poetic Justice, and Public Emotion in the Russian Hamlet (1748) 189

Kirill Ospovat 
8 The Politics of Tragedy in the Dutch Republic: Joachim Oudaen's Martyr Drama in Context 220

Nigel Smith

9 Devils On and Off Stage: Shifting Effects of Fear and Laughter in Late Medieval and Early Modern German Urban Theatre 250 Hans Rudolf Velten

10 Imagining the Audience in Eighteenth-Century Folk Theatre in Tyrol 269

Toni Bernhart

11 Nô within Walls and Beyond:Theatre as Cultural Capital in Edo Japan (1603-1868) 289

Stanca Scholz-Cionca

Index 307 


\section{Acknowledgments}

This collection arose from an international conference organised in November 2013 within the framework of the European Research Council Advanced Grant Project entitled Early Modern European Drama and the Cultural Net (DramaNet) at the Freie Universität Berlin that brought together experts on Eastern and Western early modern drama. The creative process that produced this book has been a wonderful experience of transnational scholarly collaboration. We would like to express our gratitude for the opportunity to work with excellent specialists of early modern drama in Germany and abroad, and we wish to thank all our contributors for making the effort to write, rewrite, and correct their texts, patiently waiting for the final published result. We would also like to thank the institutions and individuals who supported us throughout the organisation of the conference that inspired this volume and during the compilation of the collection itself. First, Professor Joachim Küpper, whose theoretical concepts shaped the DramaNet project, and thus the present volume. Second, the European Research Council, without whose financial support neither conference nor volume production would have been possible. Third, all DramaNet members who participated in this project at its different stages and in its various aspects, both conceptual and organisational, above all project coordinators Konstanze Ameer and Agnes Kloocke. Gratitude is also due the general editor of Drama and Theatre in Early Modern Europe, Jan Bloemendal, for his willingness to include this volume in his series, and for the care he has taken in the publication of this volume. Finally, we would like to express our thanks to Amyrose McCue Gill of TextFormations for her professional competence, enthusiasm, wise critical remarks and suggestions, and for her valuable help with the pre-production editing of the essays in this collection. 


\section{List of Illustrations and Tables}

\section{Illustrations}

1 Emblem of the Accademia degli Intronati. Frontispiece. First edition of Gl'Ingannati (1537): https://archive.org/stream/ glingannaticoniloonewb\#page/n23/mode/2up 42

2 Potta da Modena, by Master of the Metopes (twelfth century). Modena, Cathedral Lapidary Museum. Photo courtesy I. Sailko 64

3 Modena coats of arms, Sala del Fuoco, Palazzo Comunale. CC BY-SA $3.0 \quad 65$

4 Emblem of the Accademia degli Intronati (1533). Drawing. Archivio di Stato, Siena, Consistoro 100367

$5 \quad$ Palazzo Comunale, Siena. Myrabella, CC BY-SA 3.0 74

6 The Corpses of the de Witt Brothers, Jan and Cornelis, Hanging on the Groene Zoodje on the Vijverberg, The Hague, 1672', attr. Jan de Baen, 1672-c. 1675, Rijksmuseum, Amsterdam, Netherlands. The painting is in the public domain and out of copyright 230

$7 \quad$ Bauerntheater (Peasants'Theatre), by Jakob Placidus Altmutter, c. 1805. Pen-and-wash drawing, $179 \times 254$ mm. Courtesy of Innsbruck, Tiroler Landesmuseum Ferdinandeum, Grafische Sammlungen, TBar/1149 270

8 Bauerntheater in Tirol (Peasants' Theatre in Tyrol), by Adolph von Menzel, 1859. Oil on canvas, $375 \times 55^{\circ} \mathrm{mm}$. Hamburg, Hamburger Kunsthalle, bpk, Elke Walford 271

\section{Tables}

1 Distribution of plot elements, scenes, and set changes, Act I, Il favore deglidei 132

2 Distribution of plot elements, scenes, and set changes, Act II, Il favore deglidei 134

3 Distribution of plot elements, scenes, and set changes, Act III, Il favore deglidei 137 


\section{Contributor Biographies}

\section{Toni Bernhart}

is a scholar and playwright, studied German literature, theatre history, and geography at the University of Vienna and completed his dissertation on colour semantics in Hans Henny Jahnn at the Humboldt-Universität zu Berlin in 2001. He is a member of the ERC-funded project Early Modern European Drama and the Cultural Net (DramaNet), and Principal Investigator of the Deutsche Forschungsgemeinschaft-funded research project Quantitative Criticism at the University of Stuttgart. His primary research interests are German folk drama, aural perception and literature, and quantitative methods in interpretation theory. He edited the moral plays Hirlanda by Johannes Ulrich von Federspiel (1999) and Das Laaser Spiel vom Eigenen Gericht by Johann Herbst (2010); his research publications include work on Goethe, Alexander von Humboldt, Arthur Schnitzler, and Christoph Schlingensief.

\section{Déborah Blocker}

is Associate Professor of French at the University of California, Berkeley, and Affiliated Faculty in Italian Studies. She studies the social and political history of literary practices in early modern France and Italy, with a particular interest in theatre, learned societies (academies), and the development of aesthetics. Her research relies heavily on the history of the book, as well as on manuscript studies. Her first full-length study, Instituer un 'art': politiques du théâtre dans le premier XVII siècle français (2009), studied the social and political processes through which early modern French theatre was instituted into an art (1630-1660). This project enlarged her curiosity for the social and political constitution and circulation of discourses on poetry and the arts in early modern Europe (1500-1900). She is currently completing her second book-length manuscript, Le Principe de plaisir: esthétiques, savoirs et politique au sein de l'Académie des Alterati (Florence, 1569-ca. 1630). This study examines the social and political circumstances in which new conceptions of art emerged in Renaissance Florence, through an archival study of the Accademia degli Alterati that has produced a substantial number of additional publications on the academy.

\section{Logan J. Connors}

is NEH Chair in the Humanities and Associate Professor of French and Francophone Studies at Bucknell University in Lewisburg, Pennsylvania. 
A specialist of seventeenth- and eighteenth-century French theatre and literary criticism, he is also interested in current trends in literary pedagogy. He is the author of Dramatic Battles in Eighteenth-Century France: Philosophes, AntiPhilosophes and the Polemical Theatre (2012) and the editor of Pierre de Belloy's Le Siège de Calais (2014), which includes an introductory essay on the idea of patriotism in drama before 1789 . His articles have appeared in French Forum, Eighteenth-Century Fiction, The French Review, PMLA, and elsewhere both in North America and Europe. He is currently writing a book about the function of the emotions in anti- and pro-dramatic writing in France during the seventeenth and eighteenth centuries.

\section{Katja Gvozdeva}

is a member of the ERC-funded project Early Modern European Drama and the Cultural Net (DramaNet) at the Freie Universität Berlin. She studied French, Italian, and Spanish literature at the Lomonosov Moscow State University and defended her doctoral thesis on late medieval French literature at the Gorky Institute of World Literature (Russian Academy of Sciences, Moscow). Until 1999, she was Research Fellow at the Department of Comparative Literature at the Gorky Institute of World Literature. Since 1999, she has been doing research and teaching in Germany (Universität Potsdam, Technische Universität Berlin, Humboldt Universität zu Berlin, Freie Universität Berlin, Universität Tübingen). Her main research interests include late medieval and early modern European theatre and literature, carnivalesque culture, and history of literary societies. Among her publications are Risus sacer-sacrum risibile: Interaktionsfelder von Sakralität und Gelächter im kulturellen und historischen Wandel, ed. with Werner Röcke (2009); Médialité de la procession: Performance du mouvement rituel en textes et en images à l'époque pré-moderne and Scham und Schamlosigkeit: Grenzverletzungen in Literatur und Kultur der Vormoderne, both ed. with H.R. Velten (2011); and Savoirs ludiques: Pratiques de divertissement et émergence d'institutions, doctrines et disciplines dans l'Europe moderne, ed. with A. Stroev (2014).

\section{Wendy Heller}

is Professor and Chair of the Department of Music and Director of the Program in Italian Studies at Princeton University, where she specialises in the study of seventeenth- and eighteenth-century opera in interdisciplinary perspective, with an emphasis on gender and sexuality, art history, and the classical tradition. A recipient of numerous awards and fellowships, she has been a 
Mellon Fellow at the Society of Fellows of Columbia University, a Fellow of the American Academy in Rome, and an appointee at the Villa I Tatti Harvard University Center for Renaissance Studies. Winner of the Frederick Burkhardt Residential Fellowship (ACLS), she was also the Sylvan C. and Pamela Coleman Fellow at the Metropolitan Museum of Art, and is currently Vice-President of the Society for Seventeenth-Century Music. Her book Emblems of Eloquence: Opera and Women's Voices in Seventeenth-Century Venice (2003) won the Society for the Study of Early Modern Women annual book prize and was a finalist for the American Musicological Society Otto Kinkeldey Prize. Recent publications include Music in the Baroque and its companion volume Anthology of Music in the Baroque (2013), an article on Bach's Magnificat (2015), and a study of the battle between the ancients and moderns in early opera for the Oxford Handbook of Opera (2014). She is currently completing a book entitled Animating Ovid: Opera and the Metamorphoses of Antiquity in Early Modern Italy, as well as critical editions of Handel's Admeto and Francesco Cavalli's Veremonda L'Amazzone d'Aragona.

\section{Sven Thorsten Kilian}

is a member of the ERC-funded project Early Modern European Drama and the Cultural Net (DramaNet) at the Freie Universität Berlin (FUB). He was trained in French Studies and Comparative Literature at FUB and at Université de Paris 8; he was appointed Assistant Professor at Potsdam University in the Romance Languages and Literatures Department and Lecturer for French studies at FUB. His primary research interests are early modern narrative, drama, and philosophy, aesthetic theory, and twentieth-century literature. He is the author of Die Szene des Erzählens: Ereignishaftes Sprechen in 'Bagatelles pour un massacre,' 'Guignol's band' und 'Féerie pour une autre fois' von Louis-Ferdinand Céline (2012), the editor of Stadtdispositive der französischen Literatur (2013), and the co-editor of the forthcoming DramaNet volume Poetics and Politics: Net Structures and Agencies in Early Modern Drama (2016). Recent articles include studies of Gadda, Montaigne, Dante, and Botticelli; he is currently working on a project entitled Concepts of Text and Scripture in Early Modern Drama.

\section{Tatiana Korneeva}

is a Research Fellow at the Freie Universität Berlin and a member of the ERCfunded projectEarly Modern European Drama and theCultural Net(DramaNet), 2010-2016. Before beginning her postdoctoral research in Germany, she studied classical philology and comparative literature at the Lomonosov Moscow State 
University and at the Scuola Normale Superiore di Pisa, focusing on poetics, gender and cultural studies, and the relationship between literary practice and historical experience. Her articles have appeared in Modern Language Notes, German Life and Letters, Marvels and Tales, Arabeschi, Studi classici e orientali, Maia, and Italian Studies; she is the author of 'Alter et ipse': identità e duplicità nel sistema dei personaggi della 'Tebaide' di Stazio (2011). Her research interests include early modern political thought, the reception of the classical tradition, the history of theatre in comparative perspective (1400-1800), and opera studies. She is currently working on a book about the interaction between political discourse, spectatorship, and the emergent public sphere in seventeenth- and eighteenth-century Italian theatre.

\section{Kirill Ospovat}

is a member of the ERC-funded project Early Modern European Drama and the Cultural Net (DramaNet) at the Freie Universität Berlin, and a Research Associate at the National Research University Higher School of Economics (St. Petersburg). He has held postdoctoral research and teaching appointments in Munich, Berlin, London, Chicago, and Princeton. Since defending his doctoral thesis in 2005 at the Russian State University of the Humanities (Moscow), he has written on eighteenth-century Russian literary and cultural history, primarily focusing on the functioning of literary aesthetics and intellectual disciplines in early modern structures of power. His forthcoming book, Terror and Pity: Aleksandr Sumarokov and the Poetics of Power in Elizabethan Russia, which was written within the framework of the DramaNet project, illuminates the beginnings of Russian literary drama and theatre as an institution of power that must be interpreted in a pan-European, comparative, and interdisciplinary perspective.

\section{Stanca Scholz-Cionca}

is Professor of Japanese Studies at the University of Trier (until 2013), and has also taught in Munich, Berlin, and Oslo. Her fields of research span Japanese literature, comparative literature, and theatre (especially nô, kyôgen and the contemporary avant-garde). Among her publications are Aspekte des mittelalterlichen Synkretismus im Bild des Tenman Tenjin im Nô (1991); Entstehung und Morphologie des klassischen Kyôgen im 17. Jahrhundert: Vom mittelalterlichen Theater der Außenseiter zum Kammerspiel des Shogunats (1997);Japanese Theatre and the International Stage, ed. with S. Leiter (2001); Performing Culture in East Asia: China, Korea, Japan, ed. with R. Borgen (2004); Befremdendes Lachen: Komik auf der heutigen Bühne im japanisch-deutschen Vergleich, ed. 
with H.P. Bayerdörfer (2005); Nô Theatre Transversal, ed. with C. Balme (2008); and Japanese Theatre Transcultural: German and Italian Intertwinings, ed. with A. Regelsberger (2011).

\section{Nigel Smith}

is William and Annie S. Paton Foundation Professor of Ancient and Modern Literature at Princeton University. He has published mostly on early modern English literature, with interests including poetry, poetic theory, literature, politics, and religion, heresy and heterodoxy, radical literature, and the history of linguistic ideas. His major works are Perfection Proclaimed: Language and Literature in English Radical Religion 1640-1660 (1989); Literature and Revolution in England, 1640-1660 (1997); the Longman Annotated English Poets edition of Andrew Marvell's poems (2003); Is Milton Better than Shakespeare? (2008); and Andrew Marvell: The Chameleon (2010). He has edited the Ranters pamphlets (1983; rev. edn 2014); the Journal of George Fox (1999); The Oxford Handbook of Milton, with Nicholas McDowell (2009); and Mysticism and Reform, 1400-1750, with Sara S. Poor (2015). His new work, The State and Literary Production in Early Modern Europe, involves the comparison of English with literature in other European vernaculars (especially Dutch, German, French, and Spanish) in the context of political and scientific transformation between 1500 and 1800 . $\mathrm{He}$ is also writing a study of the relationship between words and music.

\section{Hans Rudolf Velten}

is Full Professor at the University of Siegen and a scholar of medieval literature and culture. He completed his habilitation at Humboldt University in 2009 and has been a Visiting Professor at the Universities of Erlangen, Saarbrücken, Cologne, and Göttingen. His research areas encompass German and European medieval and early modern literature and culture. His principal publications include Das selbst geschriebene Leben: Eine Studie zur deutschen Autobiographie im 16. Jh. (1995); the co-edited volumes Germanistik als Kulturwissenschaft, ed. with Claudia Benthien (2002); Lachgemeinschaften, ed. with Werner Röcke (2005); Medialität der Prozession / Médialité de la procession and Scham und Schamlosigkeit. Grenzverletzungen in Literatur und Kultur der Vormoderne, both ed. with Katja Gvozdeva (2011); Techniken der Sympathiesteuerung in Erzähltexten der Vormoderne-Potentiale und Probleme, ed. with Friedrich Michael Dimpel (2016). His study Scurrilitas: Die Komik des Körpers in Literatur und Kultur des Spätmittelalters und der Frühen Neuzeit will soon go into print; he is currently working on an introduction to German medieval drama entitled Theatergeschichte des Mittelalters: Eine Einführung (forthcoming, 2016). 